\title{
Dye-Sensitized Solar Cells Based on ZnO Films and Natural Dyes
}

\author{
Taher M. El-Agez ${ }^{1}$, Ahmed A. EI Tayyan ${ }^{2}$, Amal Al-Kahlout ${ }^{2}$, Sofyan A. Taya ${ }^{1, *}$, Monzir S. Abdel-Latif \\ ${ }^{1}$ Physics Department, Islamic University of Gaza, Gaza, Palestinian Authority \\ ${ }^{2}$ Physics Department, Al Azhar University, Gaza, Palestinian Authority \\ ${ }^{3}$ Chemistry Department, Islamic University of Gaza, Gaza, Palestinian Authority
}

\begin{abstract}
This work employs extracts from Walnuts, Rhubarb, and Pomegranate as natural dyes for fabrication of dye-s ensitized solar cells (DSSCs). ZnO nanoparticles with crystallite mean value $12 \mathrm{~nm}$ as confirmed from XRD data have been synthesized at $\mathrm{pH}$ 12. SEM picture of the $\mathrm{ZnO}$ powder reveals ho mogeneous and well defined nanoparticles with size of about $15 \mathrm{~nm}$. TEM micrograph shows that the powder has a porous agglomerate structure consisting main ly of spherical crystalline partic les with about $15-20 \mathrm{~nm}$ diameter. ZnO films were deposited on Fluorinated Tin Oxide (FTO) coated glass sheets followed by sintering at $450^{\circ} \mathrm{C}$. The samples were sensitized by soaking in the dye solution. A Graphite slab was used as a back electrode, and $\mathrm{I}^{-} / \mathrm{I}_{3}^{-}$redox was employed as an electrolyte. Each cell was illuminated with light intensities in the range 40,000-100,000 Lux to measure the photovoltaic parameters. The experimental results shows that the highest $I_{s c}$ value is obtained from the DSSC sensitized with Rhubarb extract while the highest $V_{o c}$ value is obtained from the DSSC sensitized with the Walnuts extract. The $P_{\max }$ of the DSSC sensitized by the Walnuts extract is greater than those sensitized by Rhubarb and Pomegranate extracts. Moreover, the open circuit voltage $V_{o c}$ decay was found to closely follow a pseudo single exponential form.
\end{abstract}

Keywords Dye-Sensitized Solar Cell, Natural Dye, Walnuts, Rhubarb, Po megranate

\section{Introduction}

Direct utilization of solar radiation to produce electricity is a steadily growing field and solar cell technology has received huge potential by physicists and engineers. Solar cells have many advantages over other energy techniques such as avoiding transmission losses, operating without noise, and requiring very little maintenance. Moreover, there are no toxic and greenhouse gas emissions in solar cell systems. Despite the considerable development in the last three decades, the high cost and the low efficiency of solar cells have been the main reasons behind the limited implementation of the technology.

Dye-sensitized solar cells (DSSCs) are promising, relatively low cost, and green energy photovoltaic devices [1-8]. A DSSC is usually comprised of a transparent conducting glass electrode coated with porous nanocrystalline wide-band gap semiconductor oxide film. The nanostructured oxide films are particularly attractive for DSSCs as they provide a large surface area for dye anchoring[9].

Dye molecules are attached to the surface of the nanos

* Corresponding author:

staya@iugaza.edu.ps (Sofyan A. Taya)

Published online at http://journal.sapub.org/ijmc

Copyright (C) 2012 Scientific \& Academic Publishing. All Rights Reserved tructured semiconductor oxide film. Photoexcitation takes place in the dye, and the photogenerated charges are separated at the dye-oxide interface. Moreover, a DSSC also comprises an electrolyte containing a reduction-oxidation couple such as $\mathrm{I}^{-} / \mathrm{I}_{3}^{-}$and a catalyst coated counter-electrode. During illumination, the cell produces voltage over and current through an external load connected to the electrodes.

It is highly significant to reduce the charge traps in thesemiconductor oxide to speed up the charge transport since the crystalline quality of the oxide film has a great effect on the charge transport. The amount of light entering the cell and the photocurrent extraction are determined by the transparent electrode. The selection of the proper semiconductor oxide and a corresponding transparent electrode is critical in the device design to achieve efficient light harvesting, charge separation, and current extraction.

The use of dye-sensitization in photovoltaics has received a great interest after the breakthrough achieved by Grätzel et al. in the early 1990's. They developed a DSSC with energy conversion efficiency exceeding $7 \%$ in 1991[10] and $11.4 \%$ in 2001[11] by combining nanostructured electrodes to efficient charge injection dyes. Since then, $\mathrm{TiO}_{2}$ nanoparticle films have been widely investigated for DSSCs. However, $\mathrm{TiO}_{2}$ films also have some defects such as the lack of a large enough energy barriers between the interface of the films and electrolytes and the existence of plenty of elec- 
tron-trapped surface states, which is the cause of the recombination[12]. The photocatalytic activity of $\mathrm{TiO}_{2}$ is so high under the UV radiation of natural sun-light that organic materials in DSSCs may be decomposed during outdoor use, resulting in long-term reliability problems for the conversion efficiency. Hence, some investigations have been turned to $\mathrm{ZnO}$ films, which have a much lower photocatalytic activity and less electron-trapped surface states[13]. However, the efficiency of $\mathrm{ZnO}$ films is still lower than that of $\mathrm{TiO}_{2}$.

The dye that is used as a photosensitizer plays an important role in the operation of DSSCs. The efficiency of the cell is critically dependent on the absorption spectrum of the dye and the anchorage of the dye to the surface of the semiconductor. Much work has been concentrated on organic dyes and organic metal complexes. On the other hand, natural dyes extracted from fruits and flowers have attracted the attention of many researchers[14-16], and many natural dyes have been proven to be efficient dyes as photosensitizers in DSSCs.

In this work, preparation of $\mathrm{ZnO}$ nanoparticles and characterization using XRD, SEM, and TEM is presented. Also, three natural dyes extracted from Walnuts, Rhubarb, and Pomegranate were investigated for dye sensitization. The absorption spectra of these extracts were studied. Besides, the performance of the DSSCs fabricated using $\mathrm{ZnO}$ nanoparticle films and extracts of these natural dyes were investigated.

\section{Experimental}

\subsection{Synthesis and Characterization of ZnO Nanoparti- cles}

$\mathrm{ZnO}$ nanoparticles used in this article have been synthesized using a method described by Rani et al.[17] by dissolving $4.4 \mathrm{~g}$ of zinc acetate dihydrate, reagent $\mathrm{Zn}\left(\mathrm{CH}_{3} \mathrm{COO}\right)_{2} \cdot 2 \mathrm{H}_{2} \mathrm{O}$ (ACROS) in $100 \mathrm{~mL}$ of methanol to obtain a $0.2 \mathrm{M}$ sol which was stirred overnight. A $3 \mathrm{M}$ aqueous solution of sodium hydroxide $(\mathrm{NaOH})$ was added dropwise to the solution under vigorous stirring. A white suspension was obtained and left under stirring for $12 \mathrm{~h}$. A $\mathrm{pH}$ meter was used to adjust the $\mathrm{pH}$ of the solution was adjusted at $\mathrm{pH} 12$. To remove the precursor material, the white slurry was washed with extra methanol. It was then dried in air at $100^{\circ} \mathrm{C}$ for $12 \mathrm{~h}$. In order to obtain a fine powder, a hammer was used to grind the powder to reduce the size of the agglomerates.

X-ray diffraction (XRD) patterns of the powder were collected on a Bruker AXS D8 powder diffracto meter unit, using $\mathrm{Cu} \mathrm{K} \alpha$ radiation $(\lambda=0.154 \mathrm{~nm})$, operating at $40 \mathrm{kV}$ and $40 \mathrm{~mA}$. A position sensitive detector (LynxEye) based on Bruker AXS compound silicon strip technology was used. The $\mathrm{ZnO}$ powders supported on glass holders were scanned between $2 \theta=10^{\circ}$ to $100^{\circ}$ with a $2 \theta$ scan step size of $0.005^{\circ}$. The structural refinement of the obtained phases and profile analysis of the related diffraction patterns were carried out using the program TOPAS, and the mean crystallite sizes were calculated using the Scherrer equation (Scherrer constant $\mathrm{k}=1$ ).

The surface morphology and the size of $\mathrm{ZnO}$ particles were analyzed using a high resolution scanning electron microscopy HR-SEM (JSM 67500F, JEOL) using secondary electron signal excited by a $10 \mathrm{keV}$ primary beam, at operating potential of $15 \mathrm{kV}$. The morphology of the particles and the particle size were determined using transmission electron microscopy (HRTEM-CM200 FEG, Philips) operating at $200 \mathrm{kV}$.

\subsection{Natural Dye Extraction}

Walnuts, Rhubarb, and Pomegranate were boiled in distilled water for many hours until solid extracts were obtained. The solid extracts were then left in an oven at $70^{\circ} \mathrm{C}$ overnight for drying purposes. Then a small amount from each extract has been dissolved in ethylene glycol.

\subsection{Prepar ation of $\mathrm{ZnO}$ Electrodes}

Fluorinated Tin Oxide $\mathrm{SnO}_{2}: \mathrm{F}\left(\mathrm{FTO}, \mathrm{K}\right.$ glass $\mathrm{R}_{\square}=8 \Omega_{\square}$ ) coated glass sheets $(1 \mathrm{~cm} \times 1 \mathrm{~cm})$, were first cleaned in a detergent solution using an ultrasonic bath for $15 \mathrm{~min}$, rinsed with water and ethanol, and then dried. An amount of $0.2 \mathrm{~g}$ of polyethylene glycol and $4 \mathrm{~mL}$ distilled water were added to two grams of $\mathrm{ZnO}$ nano-powder in order to form a paste. The resulted paste was dispersed mechanically using a home-made mill until a very soft uniform paste was obtained. Then, an a mount of $5 \mathrm{~mL}$ of ethanol was added to the paste to obtain suitable viscosity for coating purposes. The $\mathrm{ZnO}$ paste was coated on the FTO coated glass sheets. The samples were dried using a hot plate at $80^{\circ} \mathrm{C}$ followed by sintering at $450^{\circ} \mathrm{C}$ for $30 \mathrm{~min}$. then left overnight to cool down. The $\mathrm{ZnO}$ samples were sensitized by soaking the samples in the dye solutions overnight at room temperature. Then, they were washed using methyl alcohol to remove the leftover dye. Finally, they were dried using a hot plate.

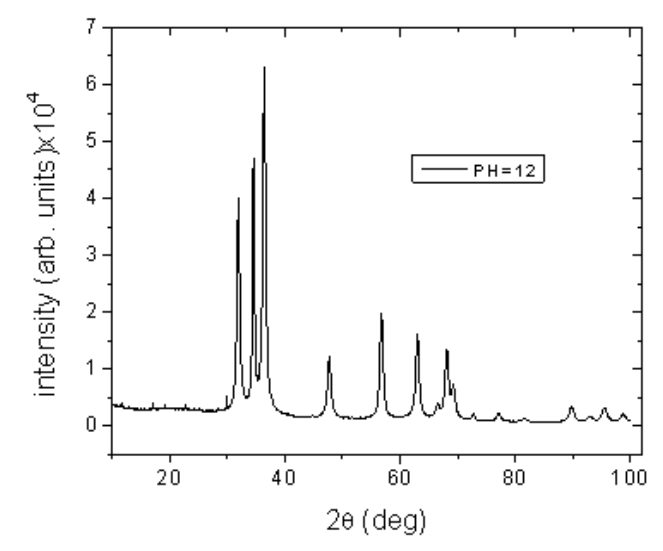

Figure 1. $\mathrm{XRD}$ pattern of $\mathrm{ZnO}$ powder synthesized at room temperat ure at $\mathrm{pH}=12$ and then dried at $100^{\circ} \mathrm{C}$ in air. The peaks corresponds to the hexagonal- wurtzite structure in the reference data (JCPDS No.0036-1451) 


\section{Results and Discussions}

\subsection{Powder Str ucture}

$\mathrm{XRD}$ pattern of the prepared $\mathrm{ZnO}$ powder is shown in Fig. 1. It is clear from the figure that the powder is highly crystalline and that its structure is in accordance with the typical wurtzite hexagonal structure (JCPDS No. 0036-1451 WL 15406 Hexagonal-03 24982). The crystallite mean value is found to be $12 \mathrm{~nm}$ and the crystallite size calculated for the (101) and (002) peaks are found to be $12 \mathrm{~nm}$ and $11 \mathrm{~nm}$, respectively. The lattice dimensions are found to $b e[a=b=$ 3.253(0) $\AA$, and $\mathrm{c}=5.213(4) \AA]$.

\subsection{Surface morphology and BET surface area analyses of $\mathrm{ZnO}$ powder}

The key points for DSSC application are surface morphology and Brunauer-Emmelt-Teller (BET) surface area. Thus it is significant to study the Surface morphology and BET surface area of the $\mathrm{ZnO}$ powder.

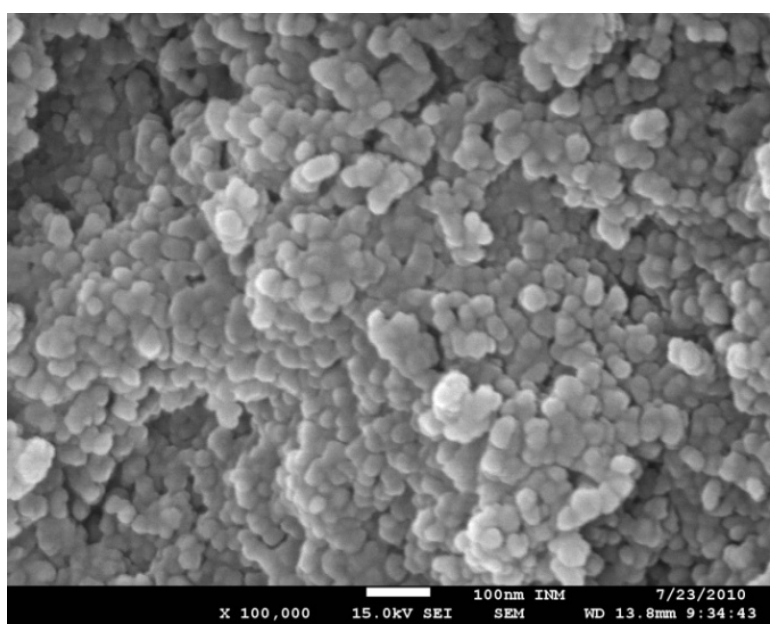

Figure 2. SEM images of the nanostructured $\mathrm{ZnO}$ powder synthesized at $\mathrm{pH} 12$. The scale bars correspond to $100 \mathrm{~nm}$

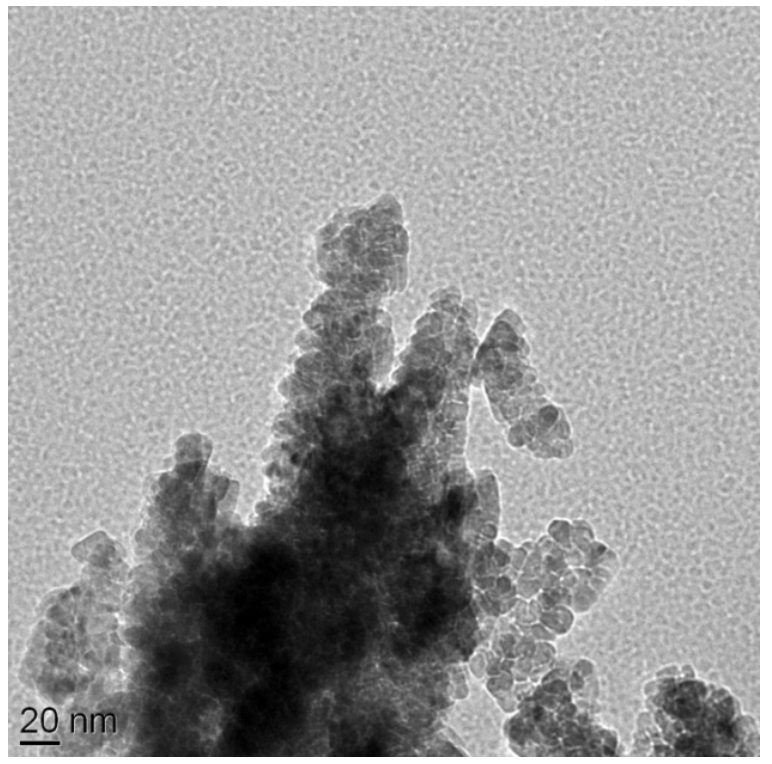

Figure 3. TEM image of the nanostructured $\mathrm{ZnO}$ powder synthesized at $\mathrm{pH} 12$ and dried at $100{ }^{\circ} \mathrm{C}$ for $12 \mathrm{~h}$. The scale bar corresponds to $20 \mathrm{~nm}$
The BET surface area of the $\mathrm{ZnO}$ powder prepared at $\mathrm{pH}$ 12 and dried at $100^{\circ} \mathrm{C}$ was $42.3 \mathrm{~m}^{2} \mathrm{~g}^{-1}$. Th is value is higher than the $23.8 \mathrm{~m}^{2} \mathrm{~g}^{-1}$ reported by Aghababazadeh et al.[18] for powders obtained by mechanochemical processing and sintered at $400^{\circ} \mathrm{C}$. This difference can be due to agglomeration of nanoparticles during sintering which accordingly reduce the surface area.

Figure 2 illustrates a SEM picture for the $\mathrm{ZnO}$ powder. The figure shows obviously that the nanoparticles are homogeneous and well defined with size of about $15 \mathrm{~nm}$.

TEM micrograph of the powder is shown in Fig. 3. It is clear that the powder has a porous agglomerate structure consisting mainly of spherical crystalline particles with about 15-20 nm diameter.

\subsection{Abs or ption s pectra}

The UV-vis absorption spectra of the three dyes were measured using a UV-vis (spectrophotometer thermoline Genesys 6). Figure 4 shows the representative UV-vis absorption spectra for the extracts of Walnuts, Rhubarb, and Pomegranate dissolved in polyethylene glycol.

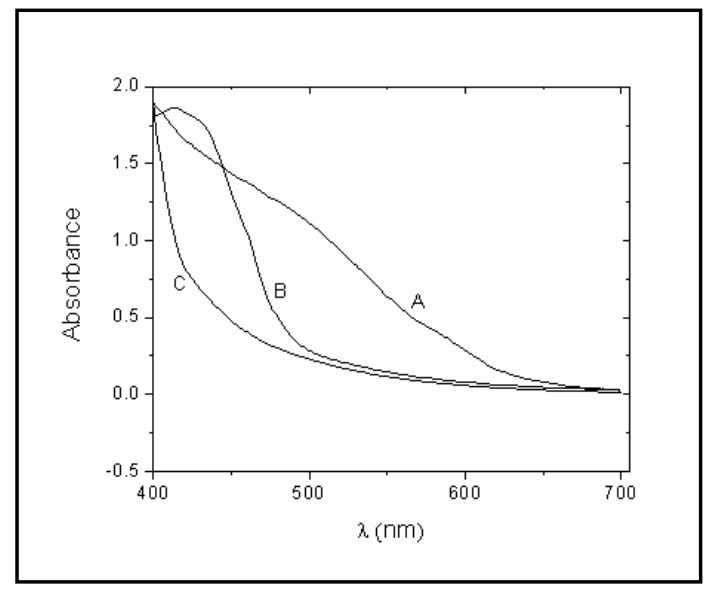

Figure 4. Light absorption spectra of (A) Walnuts extract, (B) Rhubarb extract, and (C) Pomegranate extract dissolved in polyethylene glycol

\subsection{Electrical Me asurements}

A Graphite slab was used as a back electrode. A drop of iodine-iodide redox was inserted between the back electrode and the dyed $\mathrm{ZnO}$. The $I-V$ characteristic curves at different light intensities were conducted using National instruments data acquisition card (USP NI 6251). The power $P$ was then calculated and plotted as a function of voltage $V$ and the maximum power point was determined. The $I-V$ curves of the fabricated DSSCs were obtained by applying an external reverse bias to each cell and measuring the generated photocurrent under different intensities of white light irradiation.

The incident light intensity in the range 40,000-100,000 Lux was measured and then converted to $W / \mathrm{m}^{2}$ using the simp lified relationship $[19,20]$ :

$$
\frac{E_{\text {rad }}(\operatorname{Lux})}{120,000}=\frac{E_{\text {rad }}\left(\mathrm{W} / \mathrm{m}^{2}\right)}{1,000}
$$




$$
E_{\text {rad }}\left(W / m^{2}\right)=\frac{E_{\text {rad }}(\operatorname{Lux})}{120}
$$

The $I-V$ characteristic curves of DSSCs sensitized with the extracts of Walnuts, Rhubarb, and Pomegranate are shown in Figs. 5, 6, and 7, respectively. From these figures the values of short-circuit current $\left(I_{s c}\right)$ and open-circuit voltage $\left(V_{o c}\right)$ of the cells can be obtained directly using the $I-V$ data corresponding to $10^{5} \mathrm{Lux}$ luminance. These results are tabulated in table I for the three devices. The cell output power has been calculated as $P=I \cdot V$ using the $I-V$ data corresponding to $10^{5} \operatorname{Lux}$ intensity and plotted as a function of $V$ in Fig. 8. The maximum power $\left(P_{\max }\right)$ of the DSSCs for each cell is then obtained from Fig. 8. The current $\left(I_{m p}\right)$ and the voltage $\left(V_{m p}\right)$ corresponding to the maximum power point are then obtained. The values of the fill factor $(F F)$ are calculated according to the following equation

$$
F F=\frac{I_{m p} \cdot V_{m p}}{I_{s c} \cdot V_{o c}}
$$

The efficiency $\eta$ is calcu lated as follows:

$$
\eta=\frac{F F \cdot I_{s c} \cdot V_{o c}}{E_{\text {rad }}}
$$

The highest $I_{s c}$ value is obtained from the DSSC sensitized with Rhubarb while the highest $V_{o c}$ value is obtained from the DSSC sensitized with the Walnuts. The $P_{\max }$ of the DSSC sensitized by the natural dye extract of Walnuts $(10.14 \mu \mathrm{W})$ is greater than those sensitized by Rhubarb $(8.75 \mu \mathrm{W})$ and Pomegranate $(3.85 \mu \mathrm{W})$. The lowest $P_{\max }$ value come from the DSSC sensitized with Pomegranate which may be attributed to weak bonding between the dye molecule and $\mathrm{ZnO}$ particles. Good photo-to-electric conversion ability in a DSSC is strongly dependent on available bonds between the dye molecules and $\mathrm{ZnO}$ particles, through which electrons can transport from excited dye molecules to $\mathrm{ZnO}$ film. Obviously, as a photosensitizer, the interaction and bond between sensitizer (dye) and sensitized film $(\mathrm{ZnO})$ is very important in enhancing the photoelectric conversion efficiency of a DSSC.

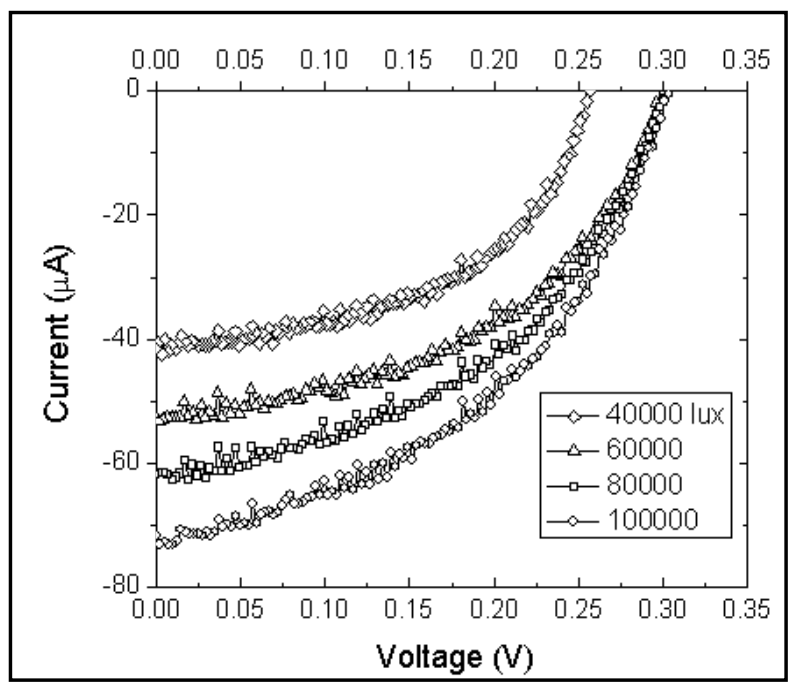

Figure 5. Current-voltage curves for the DSSC sensitized by Walnuts at different light intensities

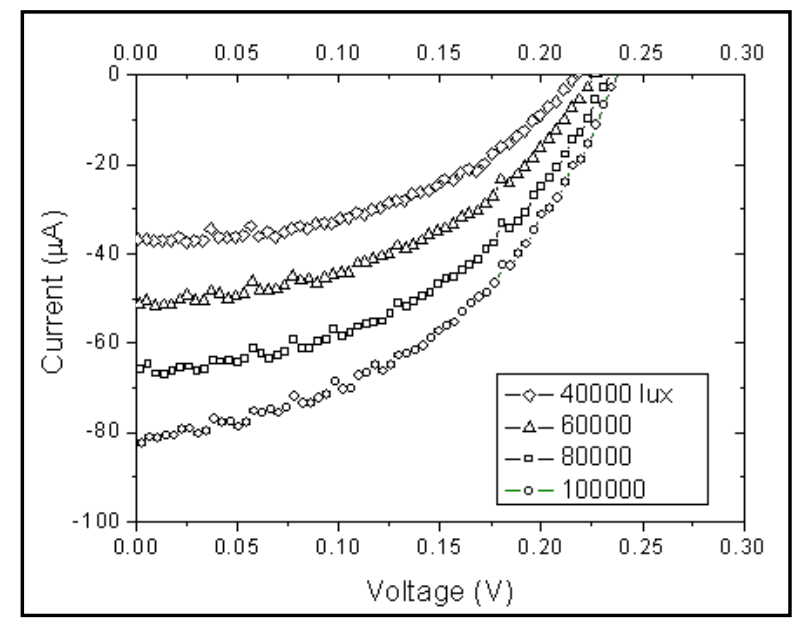

Figure 6. Current-voltage curves for the DSSC sensitized by Rhubarb at different light intensities

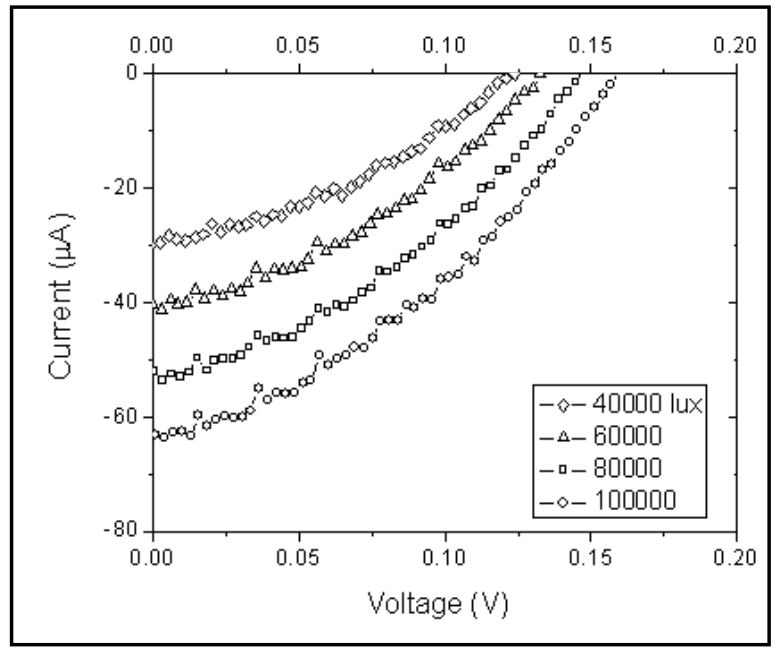

Figure 7. Current-voltage curves for the DSSC sensitized by Pomegranate at different light intensities

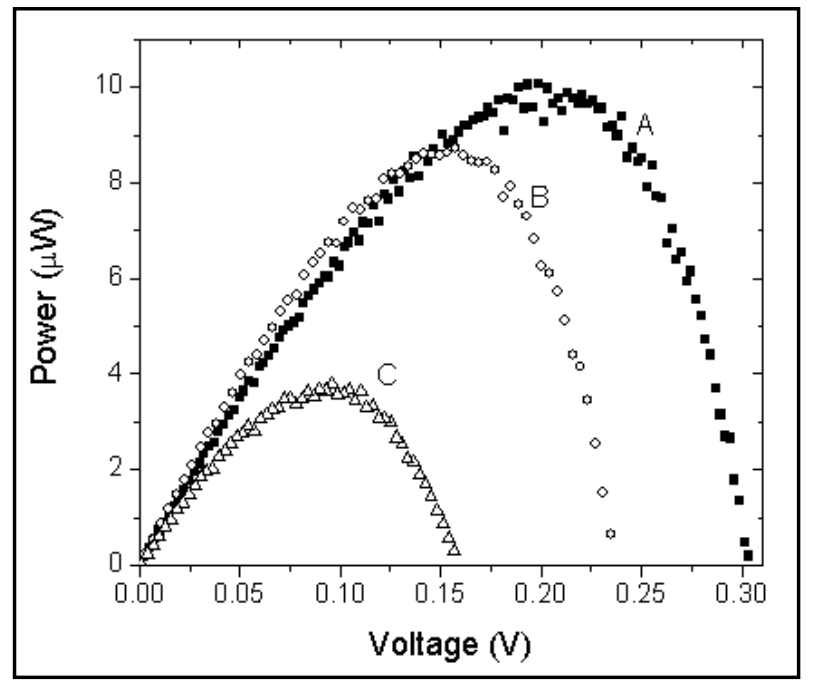

Figure 8. Power-voltage characteristics of DSSCs (A) Walnuts, (B) Rhubarb, and (C) Pomegranate in ethanol solution 
Table 1. Photoelectrical parameters corresponding to $E_{\text {rad }}=100,000$ Lux of DSSCs sensitized by natural dyes

\begin{tabular}{|c|c|c|c|c|c|c|c|}
\hline Natural dye & $\begin{array}{c}V_{o c} \\
(\mathrm{~V})\end{array}$ & $\begin{array}{c}I_{s c} \\
(\mu \mathrm{A})\end{array}$ & $\begin{array}{c}P_{\max } \\
(\mu \mathrm{W})\end{array}$ & $\begin{array}{c}V_{m p} \\
(\mathrm{~V})\end{array}$ & $\begin{array}{c}I_{m p} \\
(\mu \mathrm{A})\end{array}$ & $F F$ & $\eta(\%)$ \\
\hline Wahnuts & 0.304 & 73.3 & 10.14 & 0.198 & 49.1 & 0.39 & 0.0104 \\
\hline Rhubarb & 0.238 & 82.65 & 8.75 & 0.157 & 55 & 0.44 & 0.0104 \\
\hline Pomegranate & 0.159 & 63.2 & 3.85 & 0.096 & 37.4 & 0.36 & 0.0043 \\
\hline
\end{tabular}

Table 2. The coefficients of the $V_{o c}$ decay fitting equation for cells with the three extracts

\begin{tabular}{|c|c|c|c|c|c|}
\hline Extract & $V_{0}$ & $A_{1}$ & $t_{1}$ & $\tau_{n}$ & $k_{\text {rec }}$ \\
\hline Walnuts & 0.0872305 & -0.1703259 & -2.3029668 & 25.4855061 & 0.03924 \\
\hline Rhubarb & 0.0421363 & -0.3747801 & -6.8775522 & 8.1777440 & 0.12228 \\
\hline Pomegranate & 0.04292611 & -0.1405300 & 0.3965477 & 3.1397002 & 0.31850 \\
\hline
\end{tabular}
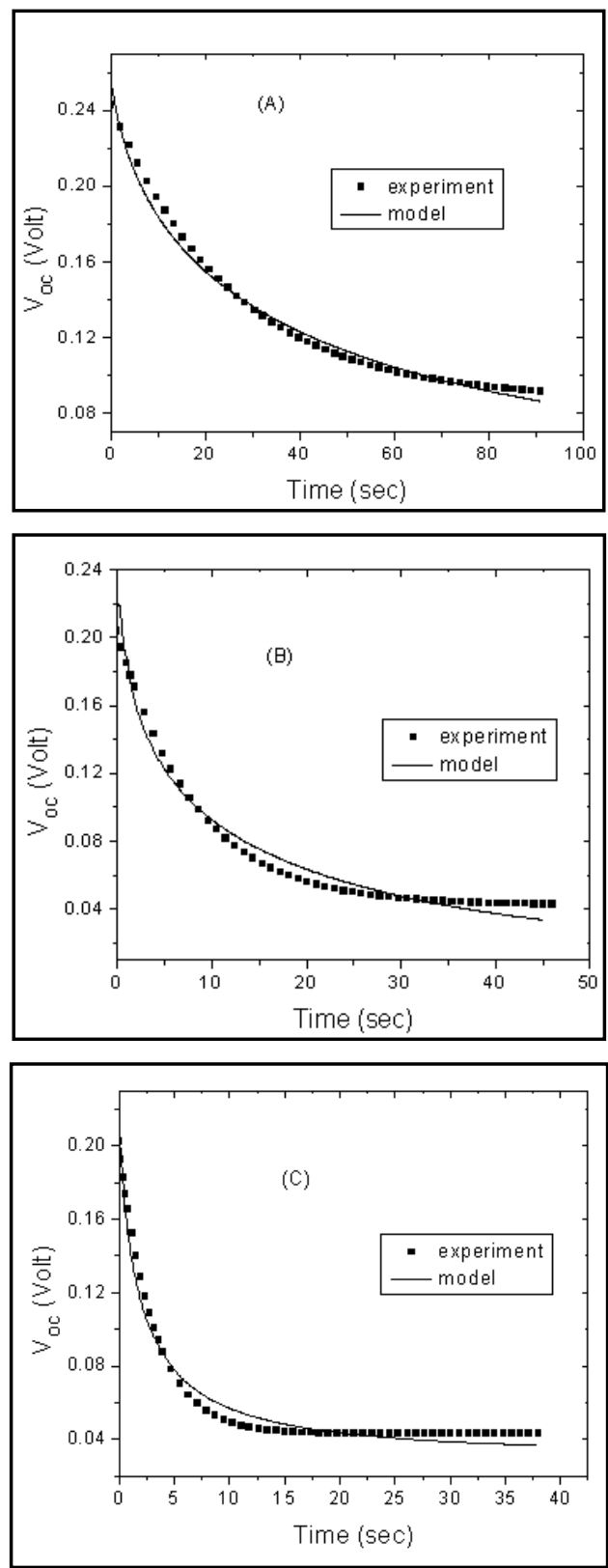

Figure 9. Open circuit voltage $V_{o c}$ decay of the cells sensitized by (A) Walnuts, (B) Rhubarb, and (C) Pomegranate extracts. Experimental data are shown in dotted lines and the fittings are presented in solid lines
Figure 9 shows the open circuit voltage $V_{o c}$ decay due to turning the light source off after illuminating the sample for few minutes. Normally, the photovoltage decay closely follows a pseudo single exponential form[21], thus the recombination rate constant, $k_{r e c}$, can be extracted from the slope of the semi-logarithmic plot. Since the back reaction is usually taken as the pseudo-first order reaction, $k_{\text {rec }}$ is related to electron lifetime $\tau_{n}$ by the relation

$$
k_{\text {rec }}=1 / \tau_{n}
$$

The data is fitted with the following equation[21]

$$
V=V_{0}-A_{1} \exp \left[-\left(t-t_{1}\right) / \tau_{n}\right]
$$

Values of the various coefficients of this fitting equation for the three cells are shown in table II.

\section{Conclusions}

Preparation and characterization of $\mathrm{ZnO}$ nanoparticles using XRD, SEM, and TEM are presented in this work. The SEM picture of the $\mathrm{ZnO}$ powder shows that the nanoparticles are homogeneous with size of about $15 \mathrm{~nm}$. The TEM micrograph indicates that the powder has a porous agglomerate structure consisting mainly of spherical crystalline particles with about $15-20 \mathrm{~nm}$ diameter. Also, we have used three natural dye extracts as photosensitizers to assemble some DSSCs. A short circuit current from $63.2 \mu \mathrm{A}$ to $82.65 \mu \mathrm{A}$, an open circuit voltage from $0.159 \mathrm{~V}$ to 0.304 $\mathrm{V}$, a fill factor from 0.36 to $0.44, \mathrm{P}_{\max }$ from $3.85 \mu \mathrm{W}$ to $10.14 \mu \mathrm{W}$, and an efficiency from $0.00431 \%$ to $0.0104 \%$ were obtained from these cells. Based on our investigation, it was found that Walnuts possesses the best photosensitization effect among three extracts of natural dyes studied. Natural dyes as alternative sensitizers for DSSCs are expected to be promising because of many reasons such as the simple preparation technique and low cost.

\section{ACKNOWLEDGEMENTS}

This research was supported by the deanery of scientific research at the Islamic university of Gaza for the academic year 2010-2011. 


\section{REFERENCES}

[1] Grätzel M., "Solar Energy Conversion by Dye-Sensitized Photovoltaic Cells", ACS Publications, Inorg. Chem., vol. 44, no.20,pp 6841-6851,2005.

[2] Wagner T., Waitz T., Roggenbuck J., Fröba M., C.-D. Kohl, M. Tiemann, "Ordered Mesoporous ZnO for Gas Sensing", Universitat Paderborn, Thin Solid Films, vol. 515, pp. 8360-8363, 2007.

[3] Nazeeruddin M.K., Kay A., Rodicio I., Humphrybaker R., Muller E., Liska P., Vlachopoulos N., Grätzel M.A., "Conversion of light to electricity by cis-X2bis(2,2'-bipyridy 1-4,4'-dicarb o xy late)ruthenium(II) charge-transfer sensitizers $(\mathrm{X}=\mathrm{Cl}-, \mathrm{Br}-, \mathrm{I}-, \mathrm{CN}-$, and $\mathrm{SCN}-)$ on nanocrystalline titanium dioxide electrodes", ACS Publications, J. Am. Chem. Soc., vol. 115, no. 14, pp. 6382-6390, 1993.

[4] Law M, Greene LE, Johnson JC, Saykally R, Yang P, "Nanowire dye-sensitized solar cells" , National Center for Biotechnology Information, Nat Mater., vol. 4, no.6, pp. 455-459, 2005.

[5] Smestad G.P., "Education and solar conversion: Demonstrating electron transfer", Sciencedirect, Sol. Energy Mater. Sol. Cells vol. 55, no. 1-2, pp. 157-178, 1998.

[6] Brian O., and Michael G., "A low-cost, high-efficiency solar-cell based on dye sensitized colloidal TiO2 films", Nature Publishing group, Nature, vol. 353, pp. 737-740, 1991.

[7] Peter L. M., "Characterization and Modeling of Dye-Sensitized Solar Cells" , National Center for Biotechnology Information, J. Phys. Chem. C, vol. 111, no. 18, pp. 6601-6612, 2007.

[8] Chou T. P., Zhang Q., Fry xell G. E., Cao G. Z., "Hierarchically Structured ZnO Film for Dye-Sensitized Solar Cells with Enhanced Energy Conversion Efficiency" WILEY, Adv. Mater., vol. 19, no. 18, pp. 2588- 2592, 2007.

[9] Chen H., Duan Z., Lu Y.G., Pasquier A. D., "Dye-sensitized solar cells combining $\mathrm{ZnO}$ nanotip arrays and nonliquid gel electrolytes", MINERALS METALS \& MATERIALS SOCIETY, Journal of ELECTRONIC MATERIALS, Vol. 38, No. 8, pp.1612-1617, 2009.

[10] O’Regan B., Grätzel M., "A low-cost, high-efficiency solar cell based on dye-sensitized colloidal TiO2 films", Nature Publishing group, Nature, vol. 353, no. 6346, pp. 737-740, 1991.

[11] Nazeeruddin M., Péchy P., Renouard T., Zakeeruddin S., Humphry-Baker R., Comte P., Liska P., Cevey L., Costa E., Shklover V., Spiccia L., Deacon G., Bignozzi C., Grätzel M., "Engineering of Efficient Panchromatic Sensitizers for Nanocry stalline $\mathrm{TiO}_{2}$-Based Solar Cells", ACS Publications, J. Am. Chem. Soc., vol. 123, no. 8, pp. 1613-1624, 2001.

[12] Longyue Z., Songyuan D., Weiwei X., Kongiia W., "Dye-Sensitized Solar Cells Based on ZnO Films", IOPScience, Plasma Science \& Technology, Vo1.8, No.2, pp.172-175, 2006.

[13] Bmer C, Boschloo G, Hagfe1d A., "Electron Injection and Recombination in Ru(dcbpy $)_{2}(\mathrm{NCS})_{2}$ Sensitized Nanostructured $\mathrm{ZnO} "$, ACS Publications, J. Phys. Chem. B, 2001, vol. 105, no. 24, pp. 5585-5588, 2001.

[14] Ito S., Saitou T., Imahori H., Ueharad H., Hasegawa N., " Fabrication of dye-sensitized solar cells using natural dye for food pigment: Monascus yellow", RSCPublishing, Energy Environ. Sci., vol.3, pp.905-909, 2010.

[15] Huizhi Zhou, Liqiong $\mathrm{Wu}$, Yurong Gao, Tingli Ma "Dye-sensitized solar cells using 20 natural dyes as sensitizers", Science Direct, Journal of Photochemistry and Photobiology A: Chemistry, vol. 219, pp.188-194,2011.

[16] Hao S., Wu J., Huang Y., Lin J., " Natural dyes as photosensitizers for dye-sensitized solar cell ", Niscair Publications, Solar Energy, vol.80, no.2, pp.209-214, 2006.

[17] Rani S., Suri P., Shishodia P.K., Mehra R.M., "Synthesis of nanocrystalline $\mathrm{ZnO}$ powder via sol-gel route for dye-sensitized solar cells", Sciencedirect, Sol. Energy Mater. Sol. Cells, vol.92, pp.1639-1645, 2008.

[18] Aghababazadeh R., Mazinani B., Mirhabibi A., Tamizifar M., "ZnO Nanoparticles Synthesised by mechanochemical processing", IOP Science, J. Phys. Conf. Ser., vol. 26, 312, 2006. doi:10.1088/1742-6596/26/1/075.

[19] Randall J. F., Jacot J., "Is AM1.5 applicable in practice? Modelling eight photovoltaic materials with respect to light intensity and two spectra", INFOSCIENCE, Renewable Energy - an International Journal, 2003.

[20] Randall J. F., Jacot J., "The performance and modelling of 8 Photovoltaic materials under variable light intensity and spectra", World Renewable Energy Congress VII \& Expo, Cologne, Germany, 2002.

[21] Zhang Z., "Enhancing the Open-Circuit Voltage of Dye-Sensitized Solar Cells: CoadSorbents and Alternative Redox Couples", PhD thesis, À LA FACULTÉ DES SCIENCES DE BASE, LABORATOIRE DE PHOTONIQUE ET INTERFACES, China, 2008. 